\title{
Two-stage technique in third molar autotransplantation: case report
}

\author{
Técnica de dois estágios no autotransplante de terceiro molar: relato de caso
}

Aécio Abner Campos PINTO JUNIOR ${ }^{1}$

(iD) ORCID iD 0000-0002-2314-0140

Savana Márcia Alves COSTA ${ }^{1}$

(iD) ORCID iD 0000-0002-7962-9818

Joanna Farias da CUNHA ${ }^{1}$

(iD) ORCID iD 0000-0003-4101-1032

Andrea Clemente PALMIER²

(iD) ORCID iD 0000-0002-1186-1688

\begin{abstract}
Tooth autotransplantation is an option for treating patients presenting early tooth loss. The teeth most commonly removed are the first molars, and their absence could lead to several oral health problems in patients. This transplant technique consists of the transposition and repositioning of a tooth from one area to another, in the same patient. Dental implants have high success rates, but tooth autotransplantation is less complex and less expensive, because the patient's own tooth is used. In the context of dental rehabilitation, tooth transplantation is focused on re-establishing masticatory function and esthetics. Success rates are variable, but in the majority of cases they exceed $80 \%$. This article aims to report the case of a patient who underwent autotransplantation of the maxillary left third molar into the maxillary right first molar position. The surgical procedure was performed on two stages. After a 3-year clinical and radiographic follow-up period, a satisfactory result was achieved with the transplanted tooth presenting a healthy pulp and periodontal tissues, reestablishing the patient's function and esthetics.
\end{abstract}

Indexing terms: Oral surgery. Organ transplantion. Third molar. Tooth.

\section{RESUMO}

O transplante dentário autógeno (autotransplante dentário) é uma opção de tratamento para pacientes que perdem dentes precocemente. Os elementos mais comumente extraídos são os primeiros molares permanentes e a falta dos mesmos pode acarretar em diversos agravos para a saúde bucal do paciente. O autotransplante dentário consiste na transposição cirúrgica e reposicionamento de um elemento dentário, de um local da boca para outro, no mesmo indivíduo. O tratamento com implantes possui elevado índice de sucesso, mas o transplante apresenta maior praticidade e menor custo, uma vez que utiliza um órgão do próprio paciente. Assim, como a reabilitação protética, tem como função o restabelecimento da mastigação e estética. As taxas de sucesso são variáveis, mas em sua maioria ultrapassam os $80 \%$. O presente trabalho relata o caso clínico de uma paciente submetida ao transplante do germe dental do elemento 28 para o alvéolo do elemento 16 . 0 ato cirúrgico foi realizado com a técnica de dois estágios e após o acompanhamento clínico e radiográfico de três anos, obteve-se um resultado satisfatório e o elemento transplantado apresentou saúde pulpar e periodontal, restabelecendo a função e a estética à paciente.

Termos de indexação: Cirurgia bucal. Transplante de órgãos. Terceiro molar. Dente.

\section{INTRODUCTION}

The first permanent molars are the teeth in the oral cavity that are most frequently lost, because they are the first permanent teeth to erupt $[1,2]$ and are often the teeth most frequently extracted in patients at an early age. The absence of this tooth may lead to migration of adjacent teeth, making it difficult to perform later rehabilitations [3]. A treatment option for patients presenting absence of the first molars, or an unfavorable prognosis for their maintenance, is tooth transplantation. This technique consists of the transfer of a tooth from one site to another, in the same person (autogenous tooth transplantation or dental autotransplantation) [4-6]. This autotransplantation procedure enables a compromised or absent tooth to be replaced by a transplanted tooth. For this purpose, impacted third molars are generally used, and they would be transferred to a prepared or existent alveolus. This treatment is also indicated for patients with congenitally absent teeth, in cases of traumatisms, iatrogenic events or when it is unfeasible to perform prosthetic restoration [3].

Dental autotransplantation consists of a treatment

\footnotetext{
${ }^{1}$ Universidade Federal de Minas Gerais, Faculdade de Odontologia. Av. Pres. Antônio Carlos, 6627, Pampulha, Belo Horizonte, MG, Brasil. Correspondência para / Correspondence to: AAC PINTO JUNIOR. E-mail: M<aeciocampos@gmail.com>.

${ }^{2}$ Universidade Federal de Minas Gerais, Faculdade de Odontologia, Departamento de Odontologia Social e Preventiva. Belo Horizonte, MG, Brasil.

$\boldsymbol{v} \mathbf{v} \mathbf{v}$

Como citar este artigo / How to cite this article

Pinto Junior AAC, SMA Costa, Cunha JF, PALMIER AC. Two-stage technique in third molar autotransplantation: case report. RGO, Rev Gaúch Odontol. 2018;66(1):96-100. http://dx.doi.org/10.1590/1981-863720180001000133388
} 
option with return esthetic and functional capacity, allowing the normal development of the arches, and preventing compromise of the temporomandibular joint. Moreover, it will avoid the insertion of dental prostheses or metal implants in young individuals [7]. The success rates of dental autotransplantations reported have ranged from 0 to $100 \%{ }^{8}$, however, studies have pointed out a success rate of close to $80 \%$ [9-11].

The aim of this report was to present a case of dental autotransplantation with a 3-year follow-up period, performed at the School of Dentistry of the Federal University of Minas Gerais.

\section{CASE REPORT}

The patient G.S.V, a 17-year-old woman, melanoderma, presented to the School of Dentistry, Federal University of Minas Gerais (UFMG) in March, 2013 and was attended in the extension project of Oral Health Promotion for Adolescents. During attendance, in the clinical and radiographic exams, the presence of extensive coronal destruction of tooth 16 was verified (Figure 1A) without any possibility of performing restorative procedures, and the presence of impacted teeth 18,28 , 38 and 48.

After explaining the treatment possibilities to the patient (and her guardian), the patient opted to undergo dental transplantation, and was thus referred to the Residence Program in Oral and Maxillofacial Surgery and Traumatology of the "Hospital das Clinicas" of UFMG. During anamnesis, no systemic changes worthy of note were detected. In the intraoral exams, painful symptoms, edema, presence of fistula on the vestibular surface of the root remainder of tooth 16 , which presented a probing depth of $2.0 \mathrm{~mm}$ at the vestibular surface; $2,0 \mathrm{~mm}$ at the palatine; $2.0 \mathrm{~mm}$ at the mesio-vestibular; $3.0 \mathrm{~mm}$ at the mesio-palatine; $5.0 \mathrm{~mm}$ at the disto-vestibular and $2.0 \mathrm{~mm}$ at the disto-palatine surfaces. Radiographic evaluation revealed the presence of periapical lesion, and by means of this analysis, measurements of the alveolus were made. Thus, the following measurements were found: $09 \mathrm{~mm}$ of clinical mesio-distal distance between teeth 15 and 17; and $5 \mathrm{~mm}$ between the alveolar bone crest and periapical lesion associated with the root remainder of tooth 16 . The following measurements were taken of all the third molars: the tooth equator (diameter); height of the mesial and distal cuspids; leading to tooth 28 being chosen to be transplanted, because it had dimensions compatible with those of the receptor bed.

To perform the dental transplant, the twostage technique, under local anesthesia was used. Extraction of the root remainder of tooth 16 (Figure 1B) and later curettage of the alveolus with a view to removing the granulation tissue were performed, without intercurrences, as was planned. At the same time, the alveolus was prepared with the aid of spherical burs, by removing $04 \mathrm{~mm}$ in the apical direction; $01 \mathrm{~mm}$ in the mesial and $01 \mathrm{~mm}$ in the distal direction, for the purpose of suiting the receptor bed to the dimensions of the tooth to be transplanted. After two weeks, we proceeded with the transfer of tooth 28 to the alveolus of tooth 16 (Figure 1C). This tooth was extracted with great care, so that the periodontal ligament and dental pulp would not be traumatized by the surgical manipulation. The same concern was considered during insertion of tooth 28 into the previously prepared alveolus. The transplanted tooth was positioned in infra-occlusion and kept in position by means of sutures (Figure 1D).
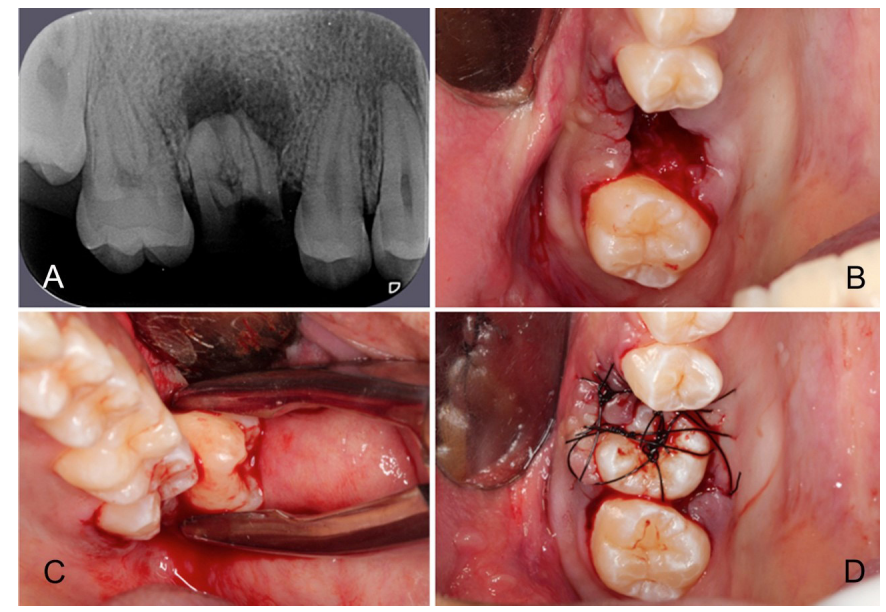

Figure 1. A) Radiographic image: note the extensive coronal destruction of tooth 16, and associated periapical lesion; B) Transoperative Image: Extraction of tooth16; C) Transoperative Image: Extraction of tooth 28 (14 days after the first procedure); D) Transoperative Image: Placement of tooth 28 in the receptor bed, maintained in position by sutures (14 days after the first procedure).

The patient was re-evaluated seven days after the surgical intervention and on clinical exam, usual healing of the surgical bed and Grade III mobility of the transplanted tooth were observed. On radiographic evaluation, the authors observed maintenance of the infra-occlusal position and aspect compatible with the post-operative period (Figure 2). Three weeks after transplantation, the tooth still presented Grade III mobility, epithelium with normal color, and no signs of 
gingival recession. The probing depth (PD) was evaluated and presented measurements of $2.0 \mathrm{~mm}$ (in the mesiovestibular, vestibular, disto-palatine and palatine regions); and $5.0 \mathrm{~mm}$ (mesio-palatine and disto-vestibular regions).

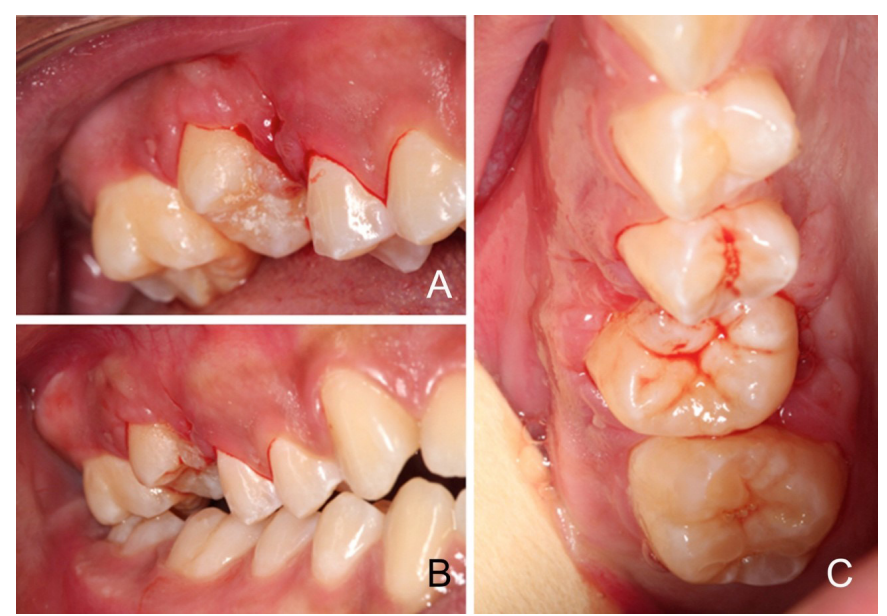

Figure 2. Intraoral image: Seventh post-operative day.

On clinical exam on the 30th post-operative day, the tooth presented a normal aspect; adjacent gingival epithelium with normal color. Grade II mobility, absence of gingival recession, absence of adhesion of the distal papilla and bacterial plaque accumulation in this region. The patient was instructed to improve cleaning in the area. The PD exam presented change only at the distopalatine and disto-vestibular surfaces, in which a PD of $3.0 \mathrm{~mm}$ associated with discrete bleeding was observed.

In the post-operative exam of one year, the authors clinically observed the absence: of pathological changes in the mucosa; physiological dental mobility; and satisfactory PD, less than $3.0 \mathrm{~mm}$ at all the surfaces of the transplanted tooth, without signs of bleeding and/or suppuration (Figures 3A, 3B). The tooth was also submitted to pulp sensitivity tests (thermal and electrical) presenting a positive response to both tests. A periapical radiographic exam was requested (Figure 3C) which enabled the authors to observe bone neoformation adjacent to the tooth in question, with an adequate level of the interproximal bone crests. After this evaluation, the patient was maintained on an annual follow-up regime, and no alterations whatever were observed in the clinical condition. At the last return (3-year postoperative follow-up) the patient presented no complaints, and all the functional and esthetic parameters observed in the previous evaluations were shown to be stable (Figure 4).

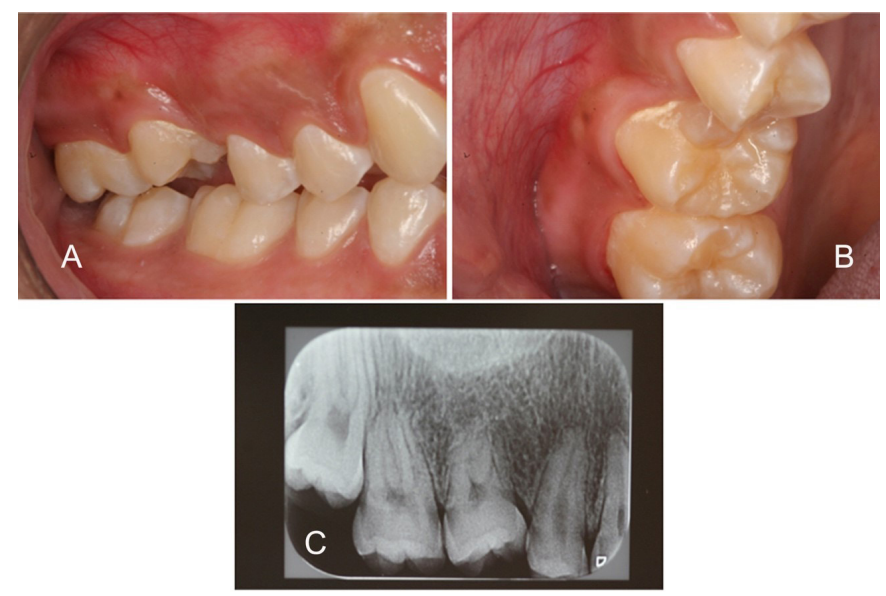

Figure 3. One year of post-operative follow-up. A, B) Intraoral image: side view in habitual maximum intercuspidation (A) and occlusal (B): C) Radiographic image: note the good adaptation of the transplanted tooth, with preservation of the interproximal bone crests and periodontal ligament space.

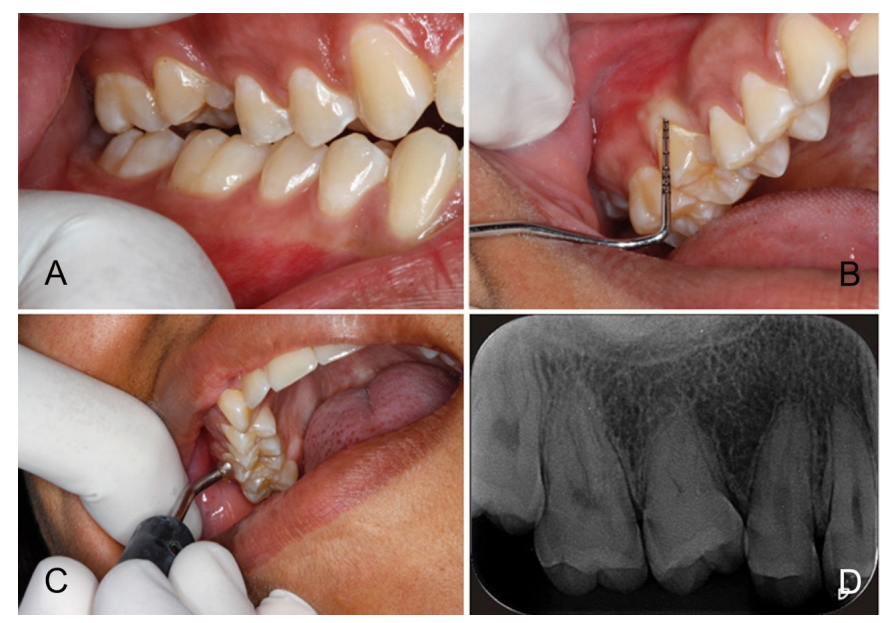

Figure 4. Thee-year post-operative follow-up. $A, B, C)$ Intraoral image: side view in habitual maximum intercuspidation (A), probing depth evaluation (B), pulp sensitivity test of the transplanted tooth (C); D) Radiographic image: note maintenance of the aspects observed in the one-year follow-up evaluation.

\section{DISCUSSION}

Dental transplantation is a feasible procedure ${ }^{11-18}$, particularly in children and adolescents, in whom prosthetic rehabilitation and by means of implants is contra-indicated $^{19}$. The teeth most commonly used for transplantation are the third molars, premolars and canines ${ }^{4,5,8,20}$, however, other teeth, including the supernumerary type may be used for this purpose ${ }^{21}$.

The cost of performing transplantations must also be considered, since it is lower than that of rehabilitation with implants, or even with dental prostheses, because no high cost materials are used ${ }^{9,22}$. Another option for the treatment of tooth loss is the use of dental prostheses, however transplantation of the natural tooth has 
the advantage of impeding alveolar bone resorption; promoting its formation ${ }^{13}$, and preserving its volume and morphology ${ }^{23}$.

The recommendation is for the donor tooth root to have $2 / 3$ to $3 / 4$ of the root formed, to favor revascularization and the complementary process of rhizogenesis ${ }^{21,24}$. At present, two techniques - of one or two stages - have been described, which are differentiated with regard to the indication of the time when the transplanted tooth will be inserted in the receptor alveolus ${ }^{21}$. The twostage technique has been shown to be more adequate than the former, because it enables the formation of granulation tissue (after a period of 14 days) which favors adaptation of the transplanted tooth to the receptor bed. Similarly, as a result of the improved vascularization in the receptor bed, the chances of successful treatment are greater ${ }^{20}$. The transplanted tooth must be positioned in infra-occlusion, at a maximum of $5 \mathrm{~mm}$ below the occlusal level of the adjacent teeth ${ }^{25}$ and the patient must strictly follow the instructions relative to hygiene. The surgery must be performed rapidly, in a time interval of less than 18 minutes - to favor preservation of the periodontal ligament ${ }^{26}$ and in an atraumatic manner, with a view to diminishing the risk of ankylosis, root resorptions and permanent infra-occlusion ${ }^{27}$. All of these associated precautions will enable treatment to be successfu|5,26,28,29. The splinting technique may be used when stabilization with sutures is not possible ${ }^{21}$.

A successful transplant is achieved when the tooth in question presents no pulp and/or inflammatory changes; signs of root resorption and demonstrates sufficient root development to support the continuous function of the tooth, confirmed by clinical and radiographic evaluation ${ }^{8,20,30}$. The transplanted tooth must be followed-up for a minimum period of one year, a time in which the chances of root resorption occurring are greatest. This has been shown to be the main factor in failure ${ }^{20}$. The most common contra-indication occurs

\section{REFERENCES}

1. Batista MJ, Rihs LB, Sousa MLR. Risk indicators for tooth loss in adult workers. Braz Oral Res. 2012;Sep-Oct;26(5):390-6. doi: $10.1590 /$ S1806-83242012000500003

2. Corraini P, Baelum V, Pannuti CM, Pustiglioni AN, Romito $\mathrm{GA}$, Pustiglioni FE. Tooth loss prevalence and risk indicators in an isolated population of Brazil. Acta Odontol Scand. 2009;67:297-303.doi: 10.1080/00016350903029107. doi: 10.1080/00016350903029107 when the tooth to be transplanted presents dimensions that are incompatible with those of the receptor area considering the mesio-distal, vestibular-lingual or apicalcoronal dimensions. Systemic complications such as cardiovascular, neurological, blood or infectious diseases may also contra-indicate the procedure ${ }^{21}$.

In the present case, the patient reported acute conditions of pain, not resolved with the use of analgesics, which frequently interfered in her quality of life. Twelve months after the surgery, the patient showed great satisfaction with the treatment, considering the esthetic and functional gains that were obtained. Moreover, she emphasized that as a result of treatment, she felt more motivated to take care of her oral hygiene, which positively influenced her interpersonal relationships.

\section{FINAL CONSIDERATIONS}

Diverse factors related to success or failure of autogenous dental transplantation must be critically evaluated. When correctly indicated and planned, transplantation presents a high level of success and low cost. Analyzing the case presented, the authors concluded that autogenous dental transplantation represents an important alternative of oral rehabilitation, allowing the return of the patient's esthetic and functional characteristics.

\section{Collaborators}

AAC PINTO JÚNIOR, writing, searching for references and was the responsible surgeon for the execution of the reported case. SMA Alves Costa: writing, searching for references and

responsible for the follow-up of the reported case. JF Cunha, orientation of the surgical procedure of the reported and case and revision of the manuscript. AC PALMIER, coordination and revision of the manuscript.

3. Sebben G, Castilhos MDS, Silva RFC. Transplantes autógenos de terceiros molares inclusos. Rev ADP-PUCRS. 2004;5:109-11.

4. Ioannidou E1, Makris GP. Twelve-year follow-up of an autogenous mandibular canine Transplant.Oral Surg Oral Med Oral Pathol Oral Radiol Endod. 2003;96(5):582-9.doi: 10.1016/ S1079210403002609.

5. Kim E1, Jung JY, Cha IH, Kum KY, Lee SJ. Evaluation of the prognosis and causes of failure in 182 cases of autogenous tooth transplantation. Oral Surg Oral Med Oral Pathol Oral Radiol Endod. 2005;100(1):112-9.doi: 10.1016/j.tripleo.2004.09.007. 
6. Natiella, JR, Armitage JE, Greene GW. The replantation and transplantation of teeth: A review. Oral Surg Oral Med Oral Pathol. 1970;29(3):397-419.

7. Cuffari L, Palumbo M. Transplante de germe do $3^{\circ}$ molar. J Bras Odontol Clín. 1997;1(2):23-7.

8. Kristerson L. Autotransplantation of human premolars:A clinical and radiographic study of 100 teeth. Int J Oral Surg. $1985 ; 14(2): 200-13$

9. Mejàre B. A prospective study on transplantation of third molars with complete root formation. Oral Surg Oral Med Oral Pathol Oral Radiol Endod. 2004;97(2):231-8.doi: 10.1016/ S107921040300461X

10. Czochrowska EM, Stenvik A, Bjercke B, Zachrisson BU. Outcome of tooth transplantation: Survival and success rates 17-41 years posttreatment. Am J Orthod Dentofacial Orthop. 2002;121(2):110-9. doi: 10.1067/mod.2002.119979

11. Kvint S, Lindstn R, Magnussonc A, Nilssond P, Bjerkline K. Autotransplantation of teeth in 215 patients. a follow-up study. Angle Orthod. 2010;80(3):446-51. doi: 10.2319/062509-354.1.

12. Souza JG. Transplante autógeno de germe de terceiro molar. RGO, Rev Gauch Odontol. 2002;50(3):175-6.

13. Waikakul A1, Punwutikorn J, Kasetsuwan J, Korsuwannawong S Alveolar bone changes in autogenous tooth transplantation. Oral Surg Oral Med Oral Pathol Oral Radiol Endod. 2011;111(3):0107.doi: 10.1016/j.tripleo.2010.11.003.

14. Jang JH, Lee SJ, Kim E. Autotransplantation of immature third molars using a computer-aided rapid prototyping model: a report of 4 cases. J Endod. 2013;39(11):1461-6. doi: 10.1016/j. joen.2013.06.026.

15. Choi SH, Hwang CJ. Orthognathic treatment with autotransplantation of a third molar. Am J Orthod Dentofacial Orthop. 2013 Nov;144(5):737-47. doi: 10.1016/j. ajodo.2012.12.013

16. Koszowski R, Morawiec $T$, Bubitek-Bogacz A. Use of the piezosurgery technique for cutting bones in the autotransplantation of unerupted third molars. Int J Periodontics Restorative Dent. 2013;33(4):477-81.doi: 10.11607/prd.0678

17. Park JM, Tatad JCI, Landayan MEA, Heo SJ, Kim SJ. Optimizing third molar autotransplantation: applications of reverse engineered surgical templates and rapid prototyping of 3D teeth. J Oral Maxillofac Surg. 2014;72:1653-59. doi: 10.1016/j. joms.2014.04.012

18. Kumar N, Prasad K, Lalitha RM, Ranganath K, Dexith J, Chauhan A. Evaluation of treatment outcome after impacted mandibular third molar surgery with the use of autologous platelet rich fibrin: a randomized controlled clinical study. J Oral Maxillofac Surg. 2015;73(6):1042-9. doi: 10.1016/j.joms.2014.11.013
19. Kallu R, Vinckier F, Politis C, Mwalili S, Willems G. Tooth transplantations: a descriptive retrospective study. Int J Oral Maxillofac Surg. 2005;34(7):745-55.doi: 10.1016/j. ijom.2005.03.009

20. Nethander G, Andersson JE, Hirsch JM. Autogenous free tooth transplantation in man by a 2-stage operation technique. A longitudinal intra-individual radiographic assessment. Int J Oral Maxillofac Surg. 1988;17(5):330-6.

21. Andreasen JO. Atlas de reimplante e transplante de dentes. São Paulo: Medicina Panamericana; 1993.

22. Yan Q, Li B, Long X. Immediate autotransplantation of mandibular third molar in China. Oral Surg Oral Med Oral Pathol Oral Radiol Endod. 2010;110:436-440. doi: 10.1016/j.tripleo.2010.02.026

23. Thomas S, Turner SR, Sandy JR. Autotransplantation of teeth: is there a role? $\mathrm{Br} J$ Orthod. 1998;25(4):275-82. doi: 10.1093/ ortho/25.4.275

24. Lundberg T, Isaksson S. A clinical follow-up study of 278 autotransplanted teeth. $\mathrm{Br} J$ Oral Maxillofac Surg. 1996;34(2):181-5

25. Bauss O, Sadat-Khonsari R, Engelke W, Kahl-Nieke B. Results of transplanting developing third molarsas part of orthodontic space management. J Orofac Orthop. 2003;64:40-47.

26. Andreasen JO. Interrelation between alveolar bone and periodontal ligament repair after replantation of mature permanent incisors in monkeys. J Periodontal Res. $1981 ; 16(2): 228-35$

27. Smith JJ, Wayman BE. Successful autotransplantation. J Endod. 1987;13(2):77-80.doi: 10.1016/S0099-2399(87)80159-0

28. Northway W. Autogenic dental transplants. Am J Orthod Dentofacial Orthop. 2002;121(6):592-3.

29. Hupp JG, Mesaros SV, Aukhil I, Trope M. Periodontal ligament vitality and histologichealing of teeth stored for extended periodsbefore transplantation. Endod Dent Traumatol. 1998; 14(2):79-83.

30. Magini RS, Schiochett C, Matteus GN, Vieira LCC. Autotransplante dental como alternativa de tratamento para perda precoce de molares permanentes. Rev Bras Odontol. 2000;57(3):170-3. 